\title{
Effect of intercropping sunflower with soybean at different inter- row and intra-row spacing on land use efficiency
}

\author{
Y. Obong, D.C. Lem and C. Opio Ogwang
}

Ngetta Zonal Agricultural Research and Development Institute, P. O. Box 52, Lira, Uganda

Author for correspondence: obong2obua@gmail.com,ngettazardi@yahoo.com

\begin{abstract}
Sunflower (Helianthus annuus L.) and soybean (Glycine max) were relatively new crops of economic significance in Uganda before 1990s compared to traditional cash crops such as cotton, tea and coffee. By 2000 many smallholder farmers in the Mid-Northern Agro-ecological Zone of Uganda started planting sunflower and soybean as sources of household income. However, sunflower and soybean are planted in same piece of land using different planting patterns that may lead to differences in yields. This study evaluated the effect of inter-row and intra-row spacing on yields of sunflower and soybean intercrop. A $4 \times 4$ factorial experiment in a randomized complete block design was used to determine performance of sunflower and soybean under four inter-row spacings $(75,90,105$ and $120 \mathrm{~cm})$ and four intra-row spacings $(30,40,50$ and $60 \mathrm{~cm})$ and sole sunflower and sole soybean. Under intercrop, a ratio of 1:1 sunflower/soybean was used. Sole sunflower was planted at $90 \mathrm{~cm} \times 30 \mathrm{~cm}$; while sole soybean was planted at $50 \mathrm{~cm} \times 25 \mathrm{~cm}$. Mean yields of sunflower from intercrop were 2517 and $1219 \mathrm{~kg} \mathrm{ha}^{-1}$, compared to 3241 and $1655 \mathrm{~kg} \mathrm{ha}^{-1}$ from sole sunflower at Acwec Omio and Ngetta Zonal Agricultural Research and Development Institute (NgeZARDI), respectively. Yield of soybean was 1100 and $2978 \mathrm{~kg} \mathrm{ha}^{-1}(\mathrm{p}<0.01)$, compared to 3364 and $2590 \mathrm{kgha}^{-1}$ from sole soybean at Acwec Omio and NgeZARDI, respectively. The highest Land Equivalent Ratios (LER) were 1.29 at inter-row spacing of $90 \mathrm{~cm}$ between rows and 1.25 at intrarow spacing of $30 \mathrm{~cm}$ within rows. The lowest LER of 0.8 was from $120 \mathrm{~cm} \times 60 \mathrm{~cm}$ spacing. An intercrop between sunflower and soybean at a spacing of $90 \mathrm{~cm}$ between rows and $30 \mathrm{~cm}$ within rows, was the most appropriate, since LER were above 1.2, an indication that land was efficiently utilized. Sunflower can be intercropped with soybean, enabling farmers to raise income by cultivating two crops in same piece of land, above all conserve the fertility of land.
\end{abstract}

Key words: Households, income, yield, LER, conserve

\section{Introduction}

Sunflower (Helianthus annuus L.) is one of the important oil crops as well a non-traditional cash crops in Uganda. Its use as raw material for oil industry has increased probably due to increased demand for oil in the country (Laker-Ojok, 
1996). Before 1990s, sunflower varieties that were being grown were ornamental/ confectionary types of Russian and Kenyan origin, with low (10-30\%) oil content. These varieties were brought by religious organisations mainly to Karamoja region. Sunflower became a popular crop with the release of new sunflower variety called Sunfola in 1995 (Laker-Ojok 1996). Since sunflower was a relatively new crop of economic significance in Uganda, there was little information about how it fitted into the farming systems. As a result, formal research tended to isolate it to just a sole crop, ignoring the mix and intercropping practices (Boquet et al., 1982 Duncan, 1986).

Then many farmers grew sunflower in lines; majority of the fields were intercropped with other crops. Mead and Willey, 1980 reported that the land equivalent ration (LER) concept is considered for situations where intercropping has to be compared with growing each crop in pure stand. Soybean is an important crop referrel to as a miracle crop in the world and has significant amount of oil as a grain legume Tukamuhabwa 2001). Although soybean was introduced in Uganda by 1908, it production was emphasized after the second world war, thereafter much work was development of new lines. Bashaasha 1992, indicated that it was by 1993 that integrated soybean project aimed at promoting soybean production and utilization started with identifying socioeconomic constraint.

Sunflower and soybean are becoming important in the farming system as source of raw material for oil. The objective of this study was to determine appropriate spacing to enable sunflower and soybean (Glycine max) to express their yield potentials and, therefore, make efficient use of limited land in Uganda.

\section{Methods and materials}

A field experiment was conducted with the Acwec Omio Farmer group and Ngetta Zonal Agricultural Research and Development Institute (NgeZARDI) in 2007 and 2008, in northern Uganda in a randomised complete block design, replicated four times. Soybean variety called Nam 1 was used in 2007 and Nam 2 was used in 2008 because the smaller size of Nam 1 made it less acceptable (Laker-Ojok 1996). Sunflower variety called Sunfola was used throughout the study. Sunflower was planted at inter-row spacing of 75, 90, 105 and $120 \mathrm{~cm}$ and intra-row spacing of $30,40,50$ and $60 \mathrm{~cm}$. Soybean was planted between two rows of sunflower at an intra-row spacing of $25 \mathrm{~cm}$. Sole sunflower was planted at 90 $\mathrm{cm}$ between the rows and $30 \mathrm{~cm}$ within row. Sole soybean crops were planted at $50 \mathrm{~cm}$ between the rows and $25 \mathrm{~cm}$ within the row. Both sunflower was thinned to one plant per hill and soybean was also thinned to one plant per hill after first weeding.

Data on plant height, head diameter, yield per plant, seed weight and yield per ha were collected for sunflower. Data that were collected on soybean were plant height, number of branches per plant, number of pods per plant, seed weight and yield per ha. Land use efficiency of intercropping was determined using Land Equivalent Ratio (LER). LER equals to Partial Land Equivalent Ratio (PLER) for sunflower plus PLER for soybean. While PLER was derived by dividing yield of sunflower and soybean from intercrop by yield of the sole crops (Willey, 1979). 
Analysis of all variables by ANOVA was performed using GenStat package Version 3.2. The significance of difference between treatments was determined using LSD at $\mathrm{P}<0.05$ (Snedecor and Cochram, 1980; Steel and Torrie, 1980).

\section{Results}

Effect of inter- and intra-row spacing on plant height, head diameter, yield plant ${ }^{-1}$ and 100 seed weight of sunflower are presented in Tables 1 and 2. Height of plants was not significantly affected by inter-row and intra-row spacing (Table 1).
Unlike plant height, head diameter was significantly affected by inter- and intra row-spacing. Wider heads of $18.06 \mathrm{~cm}$, $17.93 \mathrm{~cm}$ and $18.69 \mathrm{~cm}$ were obtained from 90, 105 and $120 \mathrm{~cm}$-wide spacings, respectively; compared with $16.28 \mathrm{~cm}$ from $75 \mathrm{~cm}$-wide spacing (Table 1). Head diameter was smaller $(16.35 \mathrm{~cm})$ when intra-row spacing was $30 \mathrm{~cm}$ compared to 40 and $60 \mathrm{~cm}$ (Table 2).

Yield per plant was also affected by inter- and intra-row spacing. Higher yield per plant was obtained when inter-row spacing were $90,105,120 \mathrm{~cm}$ than $75 \mathrm{~cm}$ wide (Table 1). Similarly, significantly

Table 1. Effect of inter-row spacing on sunflower plant parameters

\begin{tabular}{lcccc}
\hline $\begin{array}{l}\text { Inter-row } \\
(\mathrm{cm})\end{array}$ & $\begin{array}{c}\text { Plant height } \\
(\mathrm{cm})\end{array}$ & $\begin{array}{c}\text { Head diameter } \\
(\mathrm{cm})^{*}\end{array}$ & $\begin{array}{c}\text { Weight per } \\
\text { plant }(\mathrm{g})^{*}\end{array}$ & $\begin{array}{c}100 \text { seeds weight } \\
(\mathrm{g})^{*}\end{array}$ \\
\hline 75 & $167.4 \mathrm{a}$ & $16.28 \mathrm{~b}$ & $5.03 \mathrm{~b}$ & $6.04 \mathrm{~b}$ \\
90 & $169.84 \mathrm{a}$ & $18.06 \mathrm{a}$ & $6.47 \mathrm{a}$ & $6.54 \mathrm{ab}$ \\
105 & $163.97 \mathrm{a}$ & $17.93 \mathrm{ab}$ & $6.53 \mathrm{a}$ & $7.09 \mathrm{a}$ \\
120 & $163.23 \mathrm{a}$ & $18.69 \mathrm{a}$ & $6.93 \mathrm{a}$ & $6.99 \mathrm{a}$ \\
& & & & \\
$\mathrm{LSD}(0.05)$ & 7.46 & 1.30 & 1.05 & 0.65 \\
$\mathrm{CV}(\%)$ & 6.27 & 10.62 & 26.21 & 14.22 \\
\hline
\end{tabular}

* Numbers in a column followed by same letter are not significantly different at $\mathrm{P}<0.05$

Table 2. Effect of intra-row spacing on sunflower parameters

\begin{tabular}{llccc}
\hline $\begin{array}{l}\text { Inter-row } \\
(\mathrm{cm})\end{array}$ & $\begin{array}{l}\text { Plant } \\
(\mathrm{cm})\end{array}$ & $\begin{array}{c}\text { Head diameter } \\
(\mathrm{cm})^{*}\end{array}$ & $\begin{array}{r}\text { Weight per } \\
\text { plant }(\mathrm{g})^{*}\end{array}$ & $\begin{array}{c}100 \text { seeds weight } \\
(\mathrm{g})^{*}\end{array}$ \\
\hline 30 & $167.93 \mathrm{a}$ & $16.35 \mathrm{~b}$ & $5.21 \mathrm{~b}$ & $6.35 \mathrm{a}$ \\
40 & $172.13 \mathrm{a}$ & $17.53 \mathrm{a}$ & $5.65 \mathrm{a}$ & $6.56 \mathrm{a}$ \\
50 & $167.00 \mathrm{a}$ & $17.48 \mathrm{a}$ & $5.72 \mathrm{a}$ & $6.48 \mathrm{a}$ \\
60 & $167.48 \mathrm{a}$ & $18.23 \mathrm{a}$ & $6.25 \mathrm{a}$ & $6.79 \mathrm{a}$ \\
& & & & \\
LSD $(0.05)$ & 0.32 & 1.06 & 0.55 & 0.65 \\
CV $(\%)$ & 6.27 & 10.62 & 26.21 & 14.22 \\
\hline
\end{tabular}

* Numbers a in column followed by same letter are not significantly different at $\mathrm{P}<0.05$ 
higher yield per plant was obtained from 40,50 and $60 \mathrm{~cm}$-wide spacing compared to $30 \mathrm{~cm}$ (Table 2). The high yield per plant at wide spacing indicated that there was low competition among plants.

One hundred seed weight was significantly affected by inter-row spacing (Table 1). Heavy seeds were obtained from 90, 105 and $120 \mathrm{~cm}$-wide (Table 2). Seed weight from $90 \mathrm{~cm}$ and $75 \mathrm{~cm}-$ wide spacing were not significantly different. Intra-row spacing did not have significant effect on 100 seed weight.

The effect of inter- and intra-row spacing on plant height, number of branches per plant, number of branches with pods, number of pods per plant and 100 seed weight of soybean are presented in Tables 3 and 4. Inter-row spacing had a significant effect on soybean height. Soybean planted at 75 and $90 \mathrm{~cm}$ were significantly $(\mathrm{P}<0.05)$ taller than those planted at 105 and $120 \mathrm{~cm}$. There was no significant difference $(\mathrm{P}>0.05)$ in height among soybean plants spaced at 120 and $105 \mathrm{~cm}$ (Table 3). Intra-row spacing had no significant effect on soybean height.

Number of branches with pods was affected by inter-row spacing. There were significantly $(\mathrm{P}<0.05)$ more branches with pods from soybean planted at 120 and 105 $\mathrm{cm}$ compared to 90 and $75 \mathrm{~cm}$. But the number of branches with pods from 90 $\mathrm{cm}$ was not significantly different $(\mathrm{P}>0.05)$ from number of branches with pods planted at $75 \mathrm{~cm}$ (Table 3). The intra-row spacing had an effect $(\mathrm{P}<0.05)$ on number of branches with pods; whereby the number of branches with pods was significantly more from soybean plants spaced at 50 and $60 \mathrm{~cm}$ compared to 30 and $40 \mathrm{~cm}$ (Table 4).

The number of pods per plant followed a similar trend like the number of branches with pods. The number of pods per plant was significantly $(\mathrm{P}<0.05)$ more from plants spaced at $120 \mathrm{~cm}$ than at 75 and $90 \mathrm{~cm}$ spacing; although it was not significantly different from those planted at $105 \mathrm{~cm}$ spacing (Table 3).

Intra-row spacing had a significant effect on number of pods per plant (Table 4). Soybean plants from $30 \mathrm{~cm}$ and $40 \mathrm{~cm}-$ wide spacing had significantly $(\mathrm{P}<0.05)$ fewer pods per plant than to 50 and 60 $\mathrm{cm}$-wide spacing. The number of pods per plant were not significantly different from 40 and $30 \mathrm{~cm}$-wide spacing (Table 4). Planting at 50 and $60 \mathrm{~cm}$ had no significant difference in the number of pod per plant.

Table 3. Effect of inter-row spacing on soybean parameters

\begin{tabular}{lcccc}
\hline $\begin{array}{l}\text { Intra-row } \\
(\mathrm{cm})\end{array}$ & $\begin{array}{c}\text { Plant height } \\
(\mathrm{cm})^{*}\end{array}$ & $\begin{array}{l}\text { Branches } \\
\text { with pods* }\end{array}$ & $\begin{array}{c}\text { Pods } \\
\text { per plant* }\end{array}$ & $\begin{array}{c}100 \text { seeds } \\
\text { weight }(\mathrm{g})\end{array}$ \\
\hline 75 & $66.92 \mathrm{a}$ & $2.53 \mathrm{~b}$ & $43.77 \mathrm{~b}$ & $19.54 \mathrm{a}$ \\
90 & $65.48 \mathrm{ab}$ & $2.74 \mathrm{~b}$ & $45.19 \mathrm{~b}$ & $18.43 \mathrm{a}$ \\
105 & $63.52 \mathrm{~b}$ & $3.27 \mathrm{a}$ & $50.19 \mathrm{ab}$ & $18.84 \mathrm{a}$ \\
120 & $62.17 \mathrm{~b}$ & $3.28 \mathrm{a}$ & $53.79 \mathrm{a}$ & $18.88 \mathrm{a}$ \\
& & & & \\
LSD $(0.05)$ & 2.15 & 0.35 & 7.21 & 1.24 \\
CV $(\%)$ & 16.27 & 13.21 & 17.45 & 8.06 \\
\hline
\end{tabular}

* Numbers in a column followed by same letter are not significantly different at 0.05 
The effect of inter- and intra-row spacing on yield of sunflower followed a similar trend at both Acwec Omio and NgeZARDI (Fig. 1). The highest yield was obtained from a $90 \mathrm{~cm}$ spacing, followed by a $75 \mathrm{~cm}$ spacing at both Acwec Omio and NgeZARDI. The yield of plants from sole planting was significantly $(\mathrm{P}<0.05)$ higher than that from intercropped.
The result across the years indicated that higher yields were obtained at Acwec Omio compared to Ngetta. Yield of soybean was not different at both Ngetta and Acwec Omio study sites (Fig. 2). There was, however, interaction between inter-row and locations. At 75, $90 \mathrm{~cm}$ spacing and sole crop, the yield of soybean was higher at Ngetta than at Acwec Omio site. But at 105 and $120 \mathrm{~cm}$ spacing,

Table 4. Effect of intra-row spacing on soybean parameters

\begin{tabular}{lcccc}
\hline $\begin{array}{l}\text { Intra-row } \\
(\mathrm{cm})\end{array}$ & $\begin{array}{c}\text { Plant height } \\
(\mathrm{cm})^{*}\end{array}$ & $\begin{array}{c}\text { Branches } \\
\text { with pods* }\end{array}$ & $\begin{array}{c}\text { Pods } \\
\text { per plant* }\end{array}$ & $\begin{array}{c}100 \text { seeds } \\
\text { weight }(\mathrm{g})\end{array}$ \\
\hline 30 & $75.4 \mathrm{a}$ & $1.98 \mathrm{~b}$ & $26.09 \mathrm{~b}$ & $12.58 \mathrm{a}$ \\
40 & $57.9 \mathrm{~b}$ & $2.18 \mathrm{~b}$ & $25.84 \mathrm{~b}$ & $12.42 \mathrm{a}$ \\
50 & $55.3 \mathrm{~b}$ & $2.5 \mathrm{a}$ & $29.08 \mathrm{a}$ & $12.46 \mathrm{a}$ \\
60 & $58.2 \mathrm{~b}$ & $2.78 \mathrm{a}$ & $29.51 \mathrm{a}$ & $12.39 \mathrm{a}$ \\
$\mathrm{LSD}(0.05)$ & 3.11 & 0.36 & 3.76 & 0.21 \\
$\mathrm{CV}(\%)$ & 16.27 & 13.21 & 17.45 & 8.06 \\
\hline
\end{tabular}

* Numbers in a column followed by same letter are not significantly different at $\mathrm{P}<0.05$

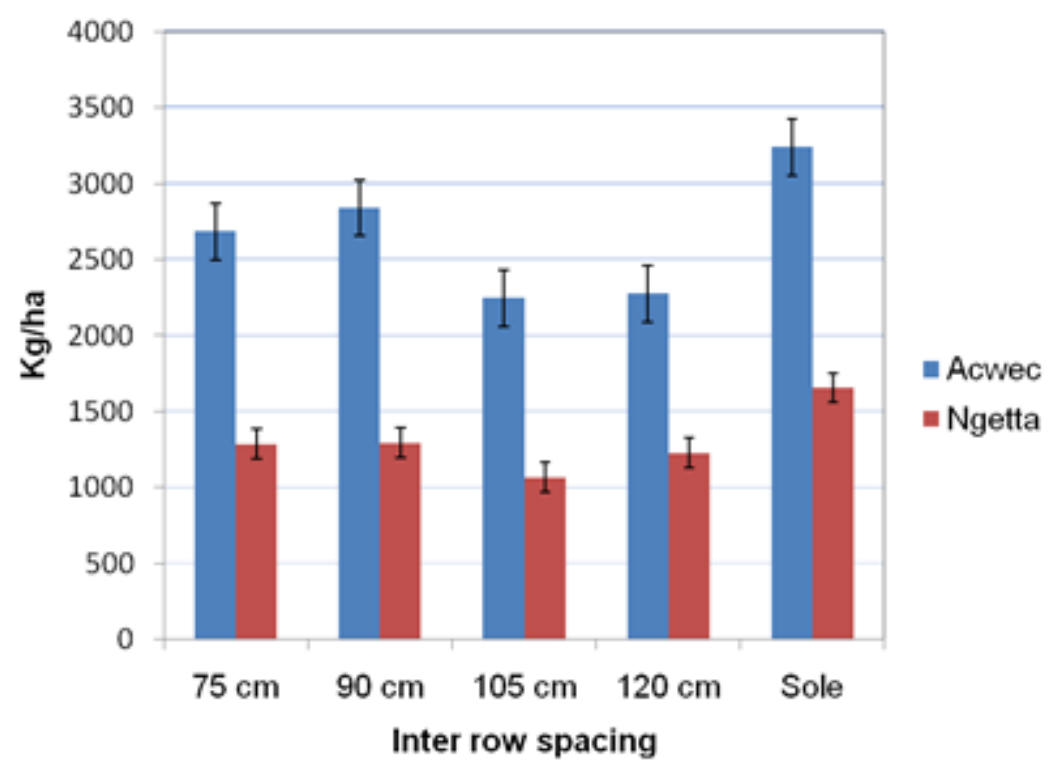

Figure 1. Grain yield of sunflower at Acwec Omio and Ngetta ZARDI sites at different interrow spacing in Uganda. 
higher yield of soybean was obtained at Acwec Omio compared to Ngetta.

The study revealed that higher yields of sunflower were obtained from 30 and $40 \mathrm{~cm}$ spacing compared to 50 and $60 \mathrm{~cm}$ (Fig. 3). The result (Fig. 3) also indicated an interaction between intra and interrow spacing. At $75 \mathrm{~cm}$ spacing, yield from 30 and $40 \mathrm{~cm}$ spacing was similar, but there was higher yield from $30 \mathrm{~cm}$ compared to $40 \mathrm{~cm}$ spacing, when the inter-row spacing was $90 \mathrm{~cm}$. At 105 and $120 \mathrm{~cm}$ inter-row, higher yield was from $40 \mathrm{~cm}$ compared to $30 \mathrm{~cm}$.

Higher yield of soybean was obtained from $50 \mathrm{~cm}$ and $60 \mathrm{~cm}$ wide spacing

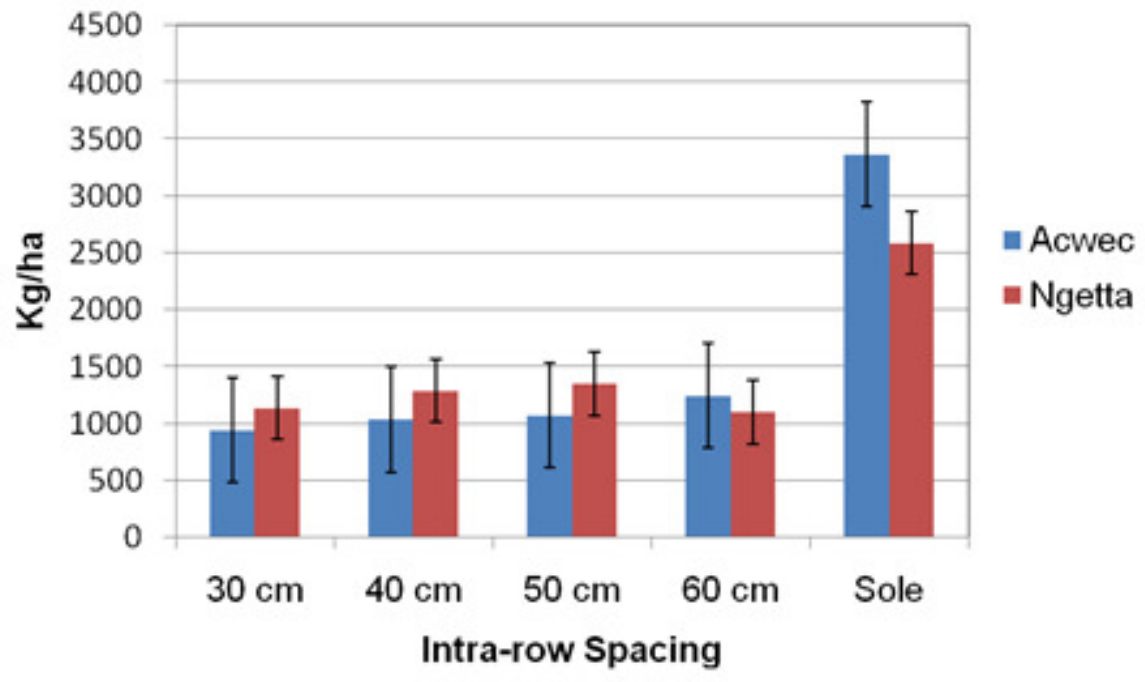

Figure 2. Grain yield of soybean at Acwec Omio and Ngetta ZARDI sites at different intrarow spacing in Uganda.

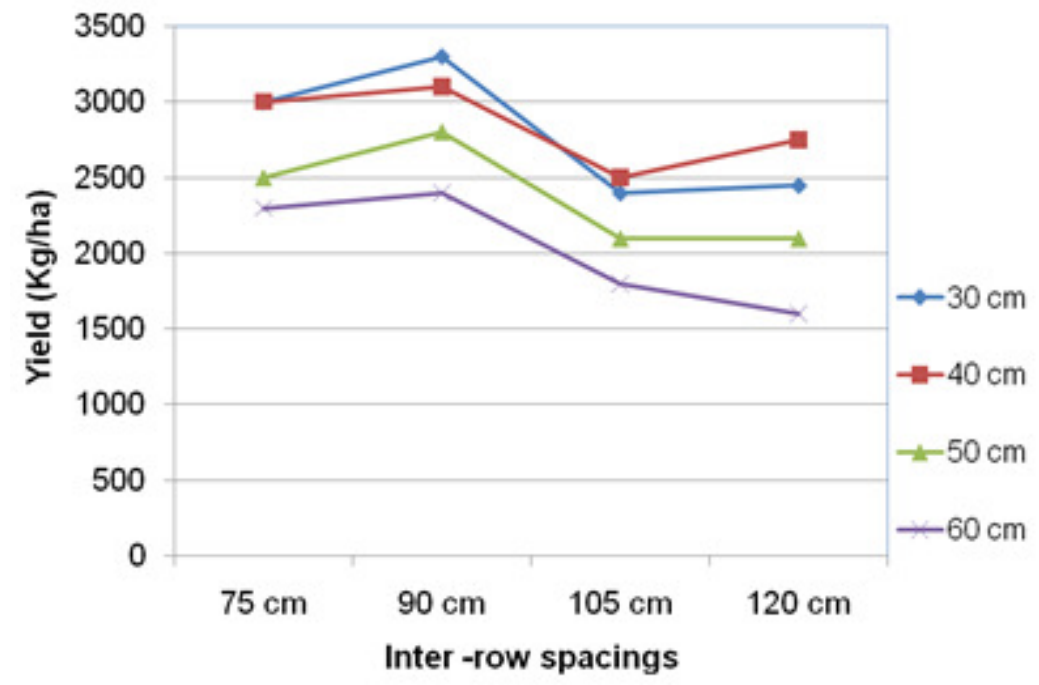

Figure 3. Effect of inter- and intra-row on average grain yield of sunflower in an intercrop with soybean at Acwec Omio and Ngetta ZARDI in Uganda. 


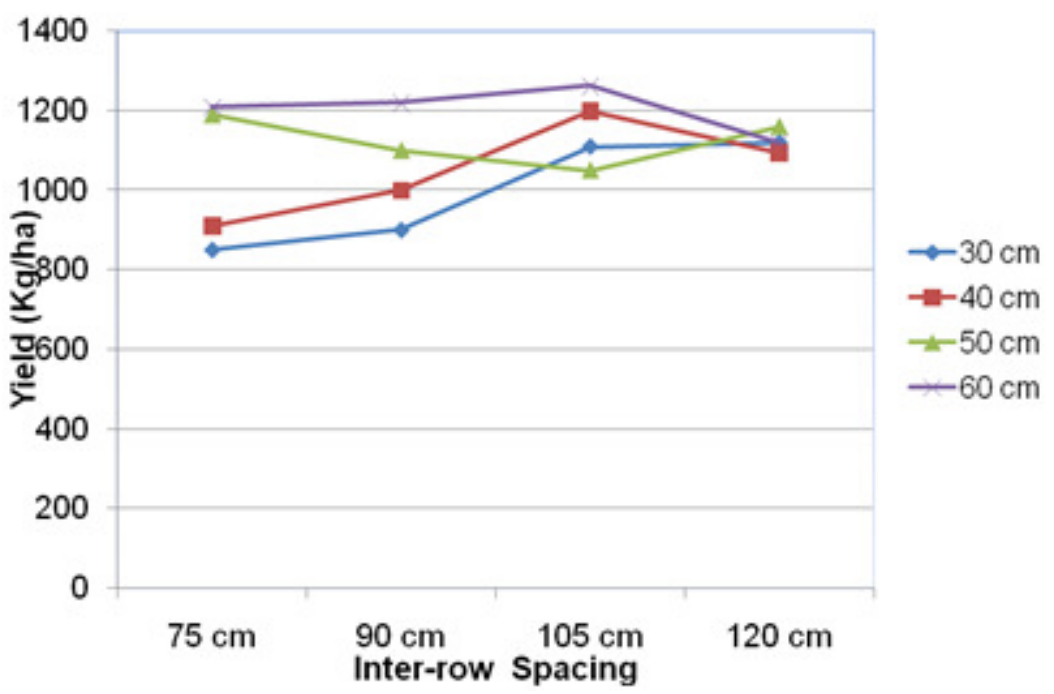

Figure 4. Effect of inter- and intra-row spacing on average grain yield of soybean in an intercrop with sunflower at Acwec Omio and NgeZARDI in Uganda.

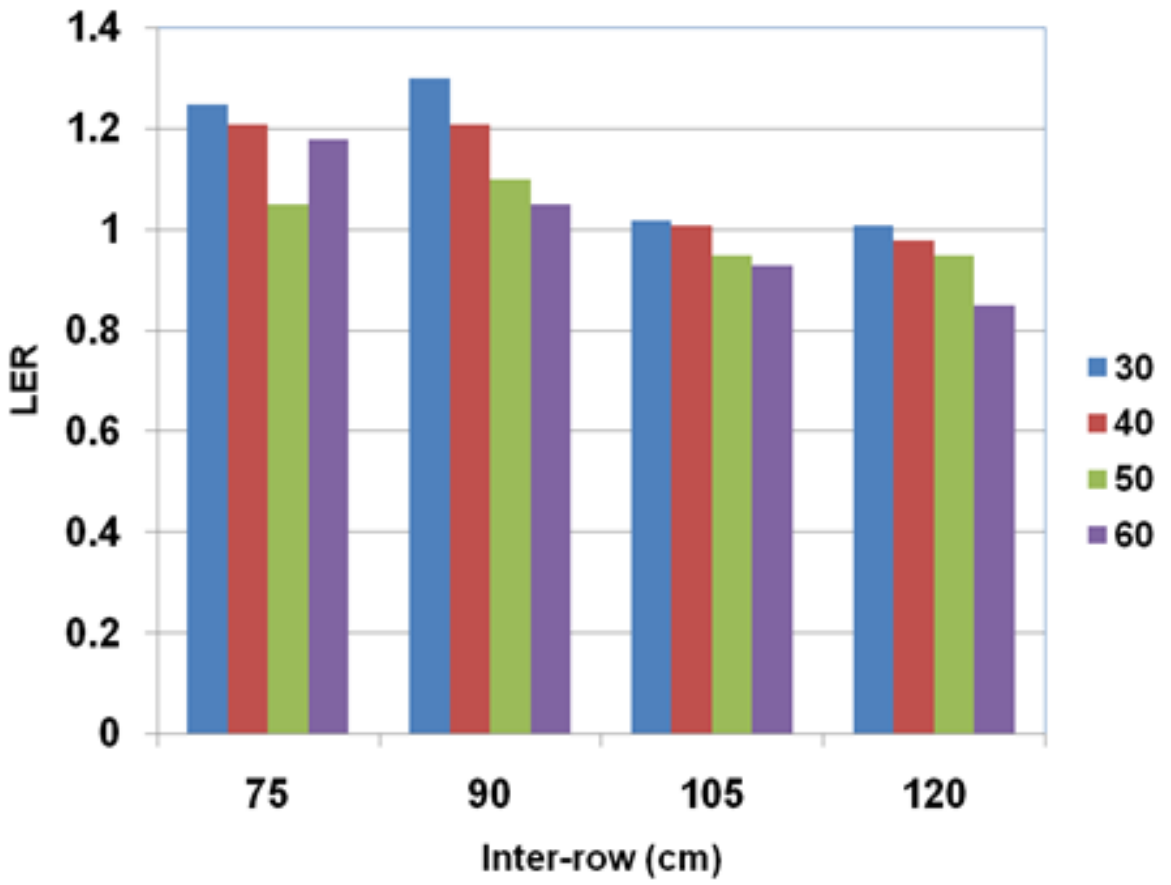

Figure 5. Effect of inter- and intra-row spacing on average Land Equivalent Ratio in a sunflower/soybean intercrop at Acwec Omio and Ngetta ZARDI in Uganda. 
compared to 30 and $40 \mathrm{~cm}$, when the inter row spacings were 75 and $90 \mathrm{~cm}$. When intra-row spacings were 30 and $40 \mathrm{~cm}$, yield of soybean increased as the interrow spacing increased up to $105 \mathrm{~cm}$; and decreased when the inter-row was 120 $\mathrm{cm}$-wide. At wider intra-row spacing, the average yield of soybean was not significantly affected (Fig. 4).

Land equivalent ratio was more than 1 at most spacing, except at $105 \mathrm{~cm} \times 60$ $\mathrm{cm}, 105 \mathrm{~cm} \mathrm{x} 50 \mathrm{~cm}, 120 \mathrm{~cm} \times 60 \mathrm{~cm}$ and $120 \mathrm{~cm}$ x $50 \mathrm{~cm}$ spacing (Fig. 5). Planting sunflower/ soybean intercrop was, therefore, appropriate at 30 and $40 \mathrm{~cm}$ wide-spacing, since LER were above 1 .

\section{Discussion}

The results indicated that average yields of sunflower and soybean were higher from Acwec Omio compared to NgeZARDI (Fig. 1). Fields in Ngetta had no records of crop rotation, suggesting some soil exhaustion due to lack of proper land use; while in Acwec Omio the land was newly cultivated. Yields of soybean and sunflower were not seriously affected by sunflower/soybean intercropping at Acwec Omio.

LER ranged from 1.29 to 0.8 at $90 \mathrm{~cm}$ x $30 \mathrm{~cm}$ and $120 \mathrm{~cm}$ x $60 \mathrm{~cm}$, respectively; an indication that soybean can be used as intercrop with sunflower (Mead et al., 1980; Olowe et al., 2006). The low LER values below 1.0 at $105 \mathrm{~cm} \times 50 \mathrm{~cm}, 105$ $\mathrm{cm} \times 60 \mathrm{~cm}, 120 \mathrm{~cm} \mathrm{x} 50 \mathrm{~cm}$ and $120 \mathrm{~cm}$ x $60 \mathrm{~cm}$ spacing were due to low plant densities of both sunflower and soybean. This was substantiated by the high yield per plant and number of branches with pods (Olowe and Adebimpe, 2009).

The significant interaction between 30 and $40 \mathrm{~cm}$ intra-row spacing need more verification. However, intercropping with sunflower spaced at $90 \mathrm{~cm} \times 30 \mathrm{~cm}$ gave the highest yield of sunflower and $105 \mathrm{~cm}$ $\mathrm{x} 40 \mathrm{~cm}$ gave the highest yield of soybean. Higher yield obtained from 30 and $40 \mathrm{~cm}$ wide spacing than 50 and $60 \mathrm{~cm}$ intra-row spacing when inter row was $90 \mathrm{~cm}$, would suggest that planting at 30 and $40 \mathrm{~cm}$ spacing would be more profitable when sunflower is the main crop.

From the result of this study, soybean can be intercropped with sunflower, since LER in most spacing is above 1 (Olowe and Adebimpe, 2009). Sunflower gave similar yield under a wide range of population density indicating its high yield elasticity (Robinson et al., 1982), hence, it is a good candidate for intercropping.

The larger the intra row spacing, the higher the yield of soybean (Fig 4). This was due to reduced competition for light and moisture.

The results from this study suggest that planting sunflower at $90 \mathrm{~cm}$-wide and 30 $\mathrm{cm}$ between plant was more efficient in utilising land under sunflower/soybean intercrop (Fig. 5). Since sunflower is becoming a major crop in the northern and eastern part of Uganda, and land pressure is increasing, there is need for a study on the nutrient balance after harvesting the intercrops.

\section{Acknowledgement}

My gratitude to everyone who supported us throughout the course of this study. Thanks to Director General and staff for the financial support and guidance. Director and staff of Ngetta ZARDI are also acknowledged.

\section{References}

Bashaasha, B.1992. Soybean research in Uganda. citeseerx.ist.psu.edu/ 
viedoc/download?doi=10.1.1.511. $867 \&$ rep=rep $1 \ldots$...pdf

Boquet, D.J., Konce, K.L. and Walker, D.M. 1982. Selected determinate soybean cultivar yield response to row spacing and planting dates. Agronomy Journal 74:136-138.

Duncan, W.G. 1986. Planting pattern and soybean yield. Crop Science 26:584588.

Laker-Ojok, R. 1996. Returns to oilseeds and maize in Uganda. Policy synthesis for USAID -Bereau for Africa Office of Sustainable Development No 27.

Mead, R. and Willey, R.W. 1980. The concept of a 'land equivalent ratio' and advantages in yields from intercropping. Experimental Agriculture 16 (3):217-228.

Olowe, V.I.O. and Adebimpe, O.A. 2009. Intercropping sunflower with soyabeans enhances total crop productivity. Biological Agriculture and Horticulture 26: 365-377.

Olowe, V.I.O., Ajayi J.A. and Ogunbayo, A.S. 2006. Potential of intercropping soybeans (Glycine max (L.) Merrill) and cowpea (Vigna unguiculata L. Walp) with sunflower (Helianthus annuus L.) in the transition zone of south west Nigeria. Tropical Agricultural Research \& Extension 9.

Robinson, R.G., Ford, J.H., Lueschen, W.E., Rabas, D.L., Smith, L.J., Warnes, D.D. and Wiersma, J.V. 1982. Response of sunflower to uniformity off plant spacing. Agronomy Journal 74:363-365

Steel, R.G.D. and Torrie, J.H. 1980. Principles and procedures of statistics: A Bio-metrical approach. $2^{\text {nd }}$ Ed. New York. McGraw-Hill International Book Company, USA. 633pp.

Tukamuhabwa, P. 2001. Soybean production in Uganda. In : Agriculture in Uganda. Vol. 2, National Agricultural Research Organisation. 572pp.

Willem Van Cotthem 2007. Sunflower in Uganda. African Agriculture/IFAD May 13, 2007.

Willey, R.W. 1979. Intercropping - Its importance and research needs. Part 1. Competition and yield advantages. Field Crop Abs. 31:1-84.

Willey, R.W. and Rao, M.R. 1980 A competitive ratio for quantifying competition between intercrops. Experimental Agriculture 16:117-125. 